体力科学 (1995) $44 ， 439 \sim 446$

複合トレーニングが人体筋のカ・速度・パワー関係に及ぼす影響

田路 秀 樹* 末 井 健 作 ${ }^{*}$ 金子公宥**

\title{
EFFECTS OF COMBINED TRAINING PROGRAMS ON FORCE-VELOCITY RELATION AND POWER OUTPUT IN HUMAN MUSCLE
}

\author{
Hideki Toji, Kensaku Suei and Masahiro Kaneko
}

\begin{abstract}
The effects of different training programs on the force-velocity relation and the maximum power output from the elbow flexor muscles were examined in eighteen male adults. The subjects were divided into three equal groups $(G 30, G 30+0, G 30+100)$. Training for $G 30$ was performed with ten repetitions at $30 \% \mathrm{P}_{0}\left(\mathrm{P}_{0}\right.$ : maximum strength), for $\mathrm{G} 30+0$ with five repetitions at $30 \% \mathrm{P}_{0}$ and five contractions with no load $\left(0 \% \mathrm{P}_{0}\right)$, and for $\mathrm{G} 30+100$ with five repetitions at $30 \% \mathrm{P}_{0}$ and five isometric contractions $\left(100 \% \mathrm{P}_{0}\right)$.

Maximum power was increased significantly in all groups after training. The amounts of power increase tended to be greatest for $G 30+100$, followed by $G 30+0$ and $G 30$. A significant difference was observed between $G 30+100$ and $G 30+0$. Maximum strength increased most in $G 30+100$. followed by $G 30$ and $G 30+0$. The strength gain in $G 30+100$ was significantly greater than that in G 30. Maximum velocity increased significantly in all groups. No significant difference in velocity gain was observed between any pair of groups.

These results suggest that isometric training at maximum strength $\left(100 \% \mathrm{P}_{0}\right)$ appears to be a more effective form of supplementary training to increase power production than would no load training at maximum velocity.
\end{abstract}

(Jpn. J. Phys. Fitness Sports Med. 1995. $44: 439 \sim 446$ )

key words : muscle force, muscle shortening velocity, muscle power, combined-training

\section{I. 銆}

筋パワーの特徴は, 力-速度関係 (force-velocity relation) ${ }^{15)}$ が示唆するように，その大きさが負荷 条件によって大きく変化し，等尺性最大筋力 (以 下，最大筋力と称する)の $30 \sim 35 \%$ の負荷条件下 で極大 (最大パワー)となる点にあり ${ }^{15,18,33)}$ ，した がって，筋パワーのトレーニングに関する組織的 な研究を行うには, 力-速度関係に対する配慮が 不可欠である.

力ー速度関係をふまえたトレーニング研究にお いて Kaneko ら ${ }^{19)}$ は,「最大パワーを効果的に高

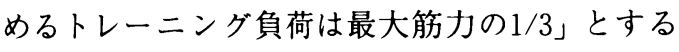
結論を示すとともに，最大筋力を発揮するトレー ニングは最大筋力の向上に, 最大速度を発揮する トレーニングは最大速度の向上に，それぞれ最も 効果的であることを報告した。森谷ら ${ }^{25)} も ， 1 / 3$ $\mathrm{P}_{0}$ 負荷のトレーニングによる最大パワーの有意 な増加を報告したが, Duchateau とHainaut ${ }^{11)}$ は, 母指内転筋の力-速度関係に対する等尺性と等張 力性のトレーニング効果を比較した中で, 等尺性 筋力トレーニング群でのみ最大パワーが有意に増 加したとする，Kaneko ら ${ }^{19)}$ とは異なった結果を 報告した。このような単一の特定運動負荷による
*姫路工業大学一般教育部

健康・スポーツ科学研究室 テ671-22 兵庫県姫路市書写2167

**大阪体育大学バイオメカニクス研究室 亍590-04 大阪府泉南郡熊取町野田1558-1
Laboratory of Health and Sport Science, Faculty of Liberal Arts, Himeji Institute of Technology, 2167 Shosha, Himeji, Hyogo 671-22, Japan

Biomechanics Laboratory, Osaka Univercity of Health and Sport Sciences, 1558-1 Noda, Kumatori, Sennan, Osaka 590-04, Japan 
トレーニングの効果は, 近年，アイソキネティッ ク装置を用いた種々速度のトレーニング (velocity-specific training)を通して調べられ，速 い運動のトレーニングは速い運動の, 遅い運動の トレーニングは遅い運動のパフォーマンスをそれ ぞれ特異的に改善するという, “トレーニングの 特異性(specificity)”が指摘されてきた

一方，複数の負荷を同時に適用する “複合トレ ーニング”の効果も検討され，筋力強化について は，短縮性と伸張性収縮の複合 ${ }^{14)}$ ，等尺性と等 張力性収縮の複合 ${ }^{2,16,23)}$, トレーニング期間の後 半に異なった内容のトレーニングを行う複合 (periodized slow-fast resistance training) ${ }^{10)}$, な どの効果が報告されている，筋収縮のスピードや 瞬発力についても，等尺性と等張力性の複合卜 レーニング (isometric-isotonic training) が腕のス イングスピードに及ほす効果 ${ }^{29,32)}$, 運動能力に 対するジャンプ, スプリント, ウエイト・トレー ニングの複合効果 ${ }^{28)}$, 疾走能力 ${ }^{9)}$ やジャンプ力 6.31)に及ほす各種複合トレーニングの効果などに ついての報告がある.田路ら ${ }^{31)}$ は, ジャンプカ の向上を目的とした複合トレーニングの研究にお いて, 垂直跳びの反復に加えて膝伸筋のアイソメ トリック・トレーニングまたはウエイト・トレー ニングを併せて行う複合トレーニングが, 垂直跳 びだけのトレーニングより効果的であることを明 らかにした。しかしこれら文献の中に，力-速度 関係や最大パワーに及ほす複合トレーニングの効 果を調べた研究は見当たらない.

そこで本研究では, 时屈筋の力-速度関係に及 ほす単一トレーニング負荷の効果を調ベた Kaneko $5^{19)}$ の研究成果と方法を参考に, 簡明な複合
トレーニングのプログラムを作成し，その力-速 度ーパワー関係に及ほす影響を検証しようとした。

\section{II. 方法}

\section{A. 被験者}

被験者は， 1 年以上特別な身体的トレーニング を行っていない工科系の男子大学生及び大学院生 18名(21〜24歳)である. 彼らの身体的特徴を(群 別に) Table 1 に示した.

\section{B. 実験装置と时屈曲運動}

肘屈曲によるトレーニング及びテストは, Wilkie $^{33)}$ の使用したものと同機構の改変型エルゴ メータ（Fig. 1)を用いて行った. 被験者はエルゴ メータを側方にして椅子に座り，上腕を机上にお いて前腕を立て，手頚部と装置が結合された状態 で肘屈曲を行う。等張力性収縮の場合は, 时関節 を $140^{\circ}$ の伸展位から $70^{\circ}$ の屈曲位まで全力で瞬 発的に屈曲する。この肘屈曲により鉄製の長アー ムが前腕と平行して回転し，短アームに吊された 荷重が引き上げられる。また等尺性収縮による最 大筋力の測定は，長アームを $90^{\circ}$ に固定して行っ た.

C. テストにおけるカ-速度関係とパワーの決定 トレーニング前と後のテストにおいて，次の方 法によりカ-速度関係とパワーを調べた. テスト 負荷は, 时関節 $90^{\circ}$ における最大筋力 $\left(\mathrm{P}_{0}\right)$ の 0 , $10 ， 20 ， 30 ， 45 ， 60 ， 100 \% \mathrm{P}_{0}$ とし，最初に軽 い負荷から重い負荷へ 2 試行づつ, 次いでその逆 の順序で 2 試行づつ(series and reverse法)の 4 試 行を各負荷条件下で行わせた。 なおここで，0\% $\mathrm{P}_{0}$ は最大速度の発揮される負荷(無荷重)であり, $100 \% \mathrm{P}_{0}$ は言うまでもなく最大筋力 $\left(=\mathrm{P}_{0}\right)$ であ

Table 1. Age and physical characteristics of subjects in each group (means \pm S. D.).

\begin{tabular}{lcccc}
\hline Groups & $N$ & $\begin{array}{c}\text { Age } \\
(\text { years })\end{array}$ & $\begin{array}{c}\text { Stature } \\
(\mathrm{cm})\end{array}$ & $\begin{array}{c}\text { Body mass } \\
(\mathrm{kg})\end{array}$ \\
\hline $\mathrm{G} 30$ & 6 & $22.0 \pm 0.8$ & $173.5 \pm 6.5$ & $60.8 \pm 5.4$ \\
$\mathrm{G} 30+0$ & 6 & $21.8 \pm 1.2$ & $170.4 \pm 7.0$ & $61.5 \pm 7.7$ \\
$\mathrm{G} 30+100$ & 6 & $22.0 \pm 1.0$ & $173.2 \pm 4.9$ & $61.0 \pm 0.9$ \\
\hline
\end{tabular}




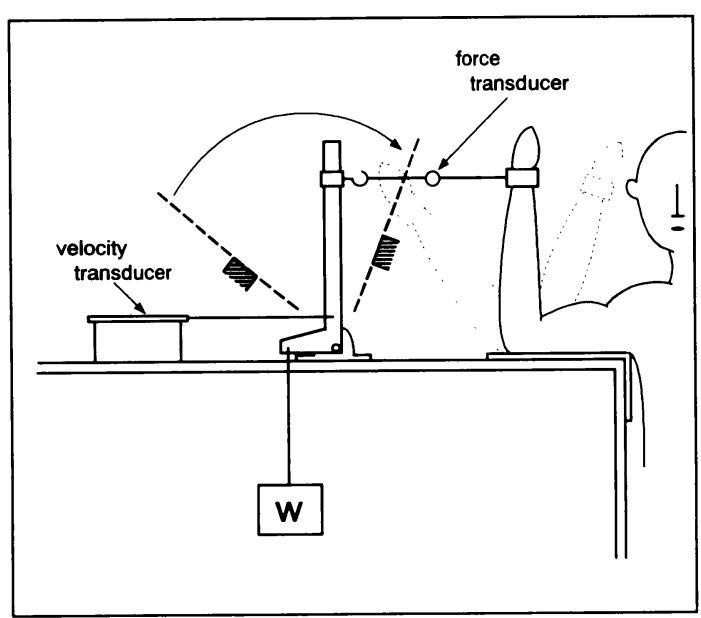

Fig. 1. The modified Wilkie's apparatus used for muscle training and for testing force-velocity relationship. Velocity $(\mathrm{V})$ and isometric strength $\left(\mathrm{P}_{0}\right)$ were measured at $90^{\circ}$ of elbow joint.

る. 等張力性収縮において発揮される力 (时関節 角 $90^{\circ}$ 付近での力) は荷重に等しいものと仮定 し19），时関節角が $90^{\circ}$ を通過するときの速度の みを計測することとして，その值を，長アームに 連結した直線型速度計 (Sheivitz 7L6VT-Z)による 速度一時間曲線から読み取った。なお，アームの 回転軸にエレクトロゴニオメータを装着して角変 位一時間曲線を同時記録し，この記録から时関節 の $90^{\circ}$ 通過時点を判定した。こうして得た手䅡部 での力と速度の值を $\mathrm{Hill}^{15)}$ の特性方程式 (次式) に当てはめて力-速度関係を得た。

$$
(P+a)(V+b)=\left(P_{0}+a\right) b
$$

ここで， $\mathrm{P}$ は力， $\mathrm{V}$ は速度， $\mathrm{P}_{0}$ は最大筋力, $\mathrm{a}$ ・ b は定数である.また，(1)式から導かれる(2)式か らパワー $(\mathrm{PV})$ を算出し，(2)式を微分した(3)式よ り最大パワー $\left(\mathrm{PV}_{\mathrm{max}}\right)$ の出現する負荷 $\left(\mathrm{P}_{\mathrm{m}}\right)$ を知っ て最大パワーを求めた。

$$
\begin{aligned}
& P V=b \cdot P\left(\frac{P_{0}+a}{P+a}-1\right) \\
& P_{m}=a\left(\sqrt{1+\frac{P_{0}}{a}}-1\right)
\end{aligned}
$$

\section{D. トレーニング方法}

本研究では被験者を 6 名づつの 3 群に分け (Table 1)，上記のエルゴメー夕を用いて週 3 日， 11週間のトレーニングを行った. 各群の 1 日のト レーニング内容は次の通りである.

1. G 30 群：最大筋力の $30 \%$ の負荷 $\left(30 \% \mathrm{P}_{0}\right)$ で 最大パワーを10回発揮する単一負荷 のトレーニング群.

2. $\mathrm{G} 30+0$ 群 : $30 \% \mathrm{P}_{0}$ で最大パワーを 5 回発 揮するとともに，0\% $\mathrm{P}_{0}$ (空振り) で最大速度を 5 回発揮する複合卜 レーニング群.

3. $\mathrm{G} 30+100$ 群 : $30 \% \mathrm{P}_{0}$ で最大パワーを 5 回 発揮するとともに, $100 \% \mathrm{P}_{0}$ (最大 筋力）を 3 秒間づつ 5 回発揮する複 合トレーニング群.

\section{E. 統計処理}

各群及び群間の平均值の差の検定には, $\mathrm{t}$-検 定を用い， $5 \%$ 末満の危険率を有意水準とした.

\section{III. 結 果}

テスト負荷の $0 ， 10 ， 20 ， 30,45,60 \% \mathrm{P}_{0}$ 負 荷に対する速度 $(\mathrm{m} / \mathrm{s})$ をそれぞれ $\mathrm{V}_{0}, \mathrm{~V}_{10}, \mathrm{~V}_{20}$, $\mathrm{V}_{30}, \mathrm{~V}_{45}, \mathrm{~V}_{60}$ とし，そのトレーニング前後の各 群における值(平均土標準偏差) と, 有意差の検定 結果を Fig. 2 に示すとともに（1)式による力-速 度曲線と(2)式による力ーパワー曲線を同図中に描 いた。 また，それら関係曲線の特徵に関する定数 を，最大筋力と最大パワーの値とともに Table 2 に示した。なお，トレーニング前における $\mathrm{PV}_{\text {max }}$, $\mathrm{P}_{0}, \mathrm{~V}_{0}$ には, いずれの群間にも有意差が認めら れなかったので,これら指標における各群の初期 条件は同等であると見なした。

最大筋力の $30 \%$ 負荷 (以下，単に $30 \%$ 負荷と略 す)で最大パワーの発揮を繰り返した G 30 群で は，比較的軽い負荷に対する速度 $\left(\mathrm{V}_{0}, \mathrm{~V}_{10}, \mathrm{~V}_{20}\right)$ に有意差のある増加が認められた，最大パワーの 発揮に加えて全力の空振りを繰り返した G $30+0$ 群では, $\mathrm{G} 30$ 群よりやや広範囲の速度 $\left(\mathrm{V}_{0}, \mathrm{~V}_{10}\right.$, $\mathrm{V}_{20}, \mathrm{~V}_{30}$ ) で有意な増加が見られた。最も著しい 増加を示したのは，30\%負荷でのトレーニングと 


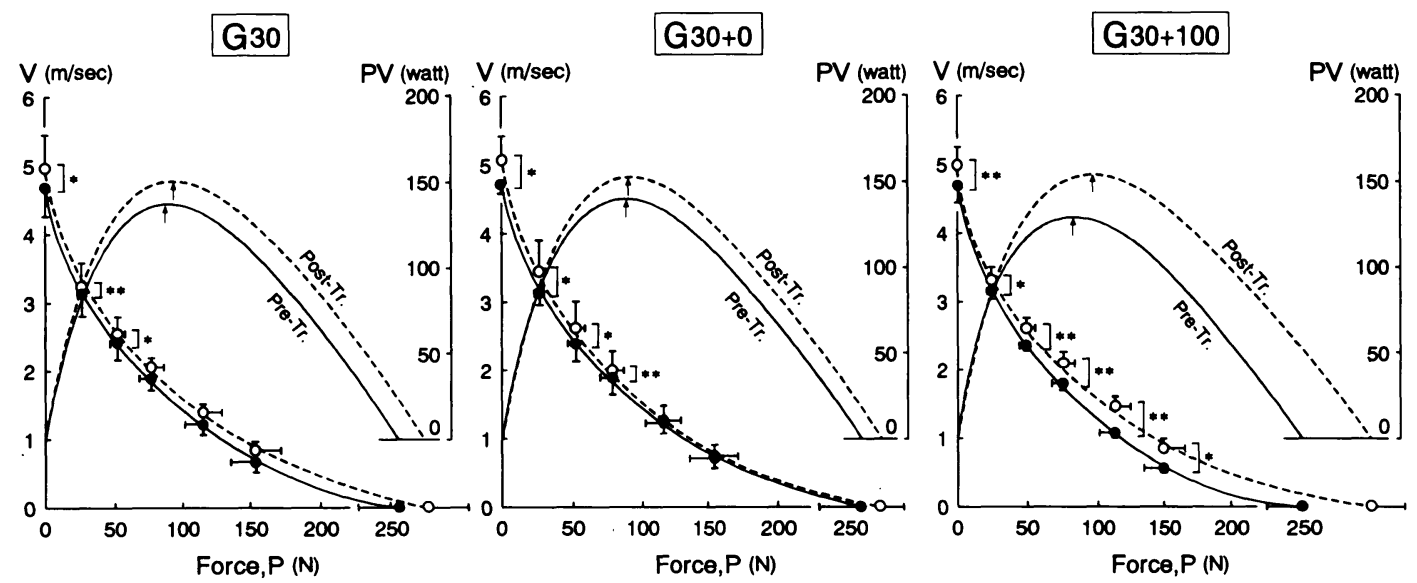

Fig. 2. The force-velocity and force-power relations at pre- and post-training periods in 3 different training groups. The arrow indicates the load at which the maximum power appeared. Significant differences between pre- and post-training periods were indicated by ${ }^{*}$ and ${ }^{* *}$ for 0.05 and 0.01 levels respectively.

Table 2. Changes in the isometrics strength $\left(\mathrm{P}_{0} ; \mathrm{N}\right)$, dynamic consants $\left(a, b\right.$ and $\left.a / \mathrm{P}_{0}\right)$ and the

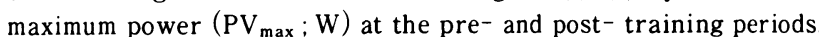

\begin{tabular}{|c|c|c|c|c|c|c|c|c|c|c|c|}
\hline \multirow{2}{*}{ Groups } & & \multicolumn{2}{|c|}{$P_{0}(N)$} & \multicolumn{2}{|c|}{ a } & \multicolumn{2}{|c|}{ b } & \multicolumn{2}{|c|}{ a / $P_{0}$} & \multicolumn{2}{|c|}{$P V_{\max }(\mathbf{W})$} \\
\hline & & Pre & Post & Pre & Post & Pre & Post & Pre & Post & Pre & Post \\
\hline G30 & $\begin{array}{r}\text { Mean } \\
\text { SD }\end{array}$ & $\begin{array}{r}256.0 \\
30.1\end{array}$ & $\begin{array}{c}274.4^{* *} \\
33.2\end{array}$ & $\begin{array}{l}97.6 \\
16.4\end{array}$ & $\begin{array}{l}98.3 \\
13.1\end{array}$ & $\begin{array}{l}1.8 \\
0.3\end{array}$ & $\begin{array}{l}1.7 \\
0.2\end{array}$ & $\begin{array}{l}0.38 \\
0.06\end{array}$ & $\begin{array}{l}0.36 \\
0.06\end{array}$ & $\begin{array}{r}139.8 \\
25.3\end{array}$ & $\begin{array}{c}153.3^{*} \\
25.6\end{array}$ \\
\hline G30+0 & $\begin{array}{r}\text { Mean } \\
\text { SD }\end{array}$ & $\begin{array}{r}258.1 \\
30.0\end{array}$ & $\begin{array}{r}272.6 \\
17.7\end{array}$ & $\begin{array}{l}94.2 \\
14.8\end{array}$ & $\begin{array}{l}91.7 \\
12.3\end{array}$ & $\begin{array}{l}1.8 \\
0.5\end{array}$ & $\begin{array}{l}1.7 \\
0.4\end{array}$ & $\begin{array}{l}0.38 \\
0.09\end{array}$ & $\begin{array}{l}0.34 \\
0.06\end{array}$ & $\begin{array}{r}138.0 \\
10.1\end{array}$ & $\begin{array}{l}151.8^{* *} \\
16.1\end{array}$ \\
\hline $\mathrm{G} 30+100$ & $\begin{array}{r}\text { Mean } \\
\text { SD }\end{array}$ & $\begin{array}{r}249.9 \\
26.2\end{array}$ & $\begin{array}{c}294.7^{*} \\
29.9\end{array}$ & $\begin{array}{r}82.8 \\
6.8\end{array}$ & $\begin{array}{l}91.2 \\
17.8\end{array}$ & $\begin{array}{l}1.6 \\
0.1\end{array}$ & $\begin{array}{l}1.5 \\
0.2\end{array}$ & $\begin{array}{l}0.34 \\
0.02\end{array}$ & $\begin{array}{l}0.31 \\
0.05\end{array}$ & $\begin{array}{r}129.0 \\
14.0\end{array}$ & $\begin{array}{c}154.2^{* *} \\
23.6\end{array}$ \\
\hline
\end{tabular}

* indicates significant difference at 0.05 level and ${ }^{* *}$ at 0.01 level in comparison with pre-training value.

最大筋力発揮のトレーニングを複合した G $30+$ 100 群で，すべての速度 $\left(\mathrm{V}_{0} \sim \mathrm{V}_{60}\right)$ において統計 的に $5 \%$ 水準以上の有意な増加が認められた (Fig. 2).

また, 最大筋力 $\left(\mathrm{P}_{0}\right)$ は $\mathrm{G} 30$ 群と $\mathrm{G} 30+100$ 群 において, 最大パワー $\left(\mathrm{PV}_{\max }\right)$ はすべての群にお いて，それぞれ有意な増加が認められたが，定数 $\left(\mathrm{a}, \mathrm{b}, \mathrm{a} / \mathrm{P}_{0}\right)$ についてはいずれの定数にも有意な 変化が見られなかった(Table 2).

力, 速度, パワーの最大値である最大筋力, 最 大速度, 最大パワーを取り上げ，それらのトレー ニングによる増加量とその有意性, 及び群間の差
の有意性を Fig. 3 に示した. 最大パワーの増加 量 $\left(+\Delta \mathrm{PV}_{\max }\right)$ は $\mathrm{G} 30+100$ 群で最も多く, G 30 +0 群と G 30 群では互いにほほ同程度で, G 30 +100 群と $\mathrm{G} 30+0$ 群の増加量間に有意差 $(\mathrm{p}<$ $0.05)$ が認められた。最大筋力の増加量 $\left(+\Delta \mathrm{P}_{0}\right)$ は G $30+100$ 群で最も多く, 次の $\mathrm{G} 30$ 群の増加 量との間に有意差 $(\mathrm{p}<0.05)$ が認められた。最大 速度における各群の増加量 $\left(+\Delta \mathrm{V}_{0}\right)$ はほほ同程度 で,いずれの群間にも有意差が認められなかった。

\section{N.}

“トレーニングの特異性 (specificity)”を指摘し 

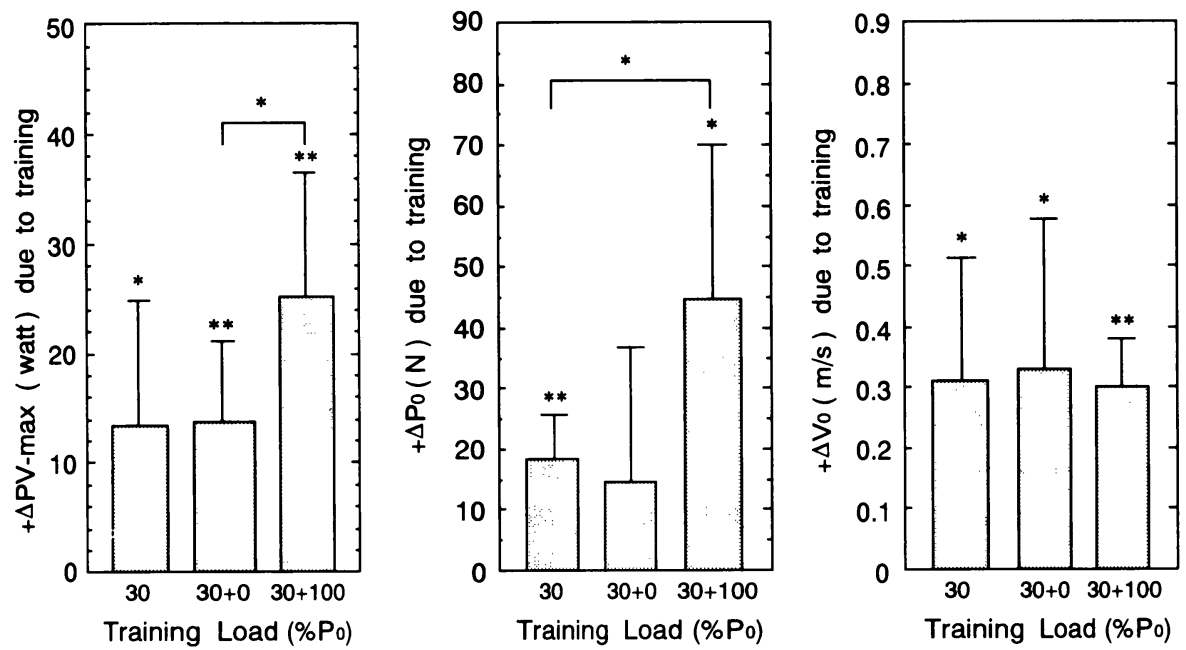

Fig. 3. Changes in isometric strength $\left(\mathrm{P}_{0}\right)$, maximum velocity $\left(\mathrm{V}_{0}\right)$ and maximum power $(\mathrm{PVmax})$ due to training. Significant differences at 0.05 and 0.01 levels were indicated by ${ }^{*}$ and ${ }^{* *}$ respectively.

た研究の運動プログラムは，そのほとんどが単一 の運動負荷を用いて行う，言わば “単一(負荷)卜 レーニング” で3,7,17,19〜22,27), 複合トレーニン グ (combined training)のかたちで行われる実際の トレーニングとは異なる.

複合トレーニングに関しては, Smith ${ }^{29)}$ が等 尺性収縮と等張力性収縮の複合トレーニング (isometric-isotonic training)による筋力とスピー

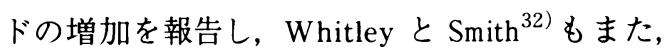
腕のスイングスピードを高めるには, isometricisotonic training が等張力性のみのトレーニング と同様に有効であることを報告している.しかし， 同様のトレーニングを行った Belka ${ }^{2)}$ の研究では, 等尺性筋力は増加せず，等張力性筋力にのみ有意 な増加が認められた. Hakkinen ら ${ }^{14)}$ は, 競技選 手の筋力トレーニングにおいて，短縮性収縮と伸 張性収縮の複合トレーニングが顕著な効果をもた らしたとし，また Jackson ${ }^{16)}$ は, ウエイト・トレー ニングの動作中に通過しにくい姿勢(スティッキ ング・ポイント)があることから, 日常のウエイ ト・トレーニングに加えてスティッキング・ポイ ントでの等尺性筋カトレーニングを行わせたとこ ろ著名な効果がみられたと報告している．筋力ト レーニングを複合した本研究の G $30+100$ 群の
トレーニング(上記 isometric-isotonic training に 相当)は, その最大筋力に及ほす効果が他の2群よ り明らかに顕著であり, 最大スピードと最大パ ワーに対しても，有効であることを示した。

パワーないし瞬発力に及ほす複合トレーニング の効果について, Schultz ${ }^{28)}$ は, 立ち幅跳びと筋 カトレーニングを組み合わせた複合トレーニング が立ち幅跳びだけを行うトレーニングより有効で

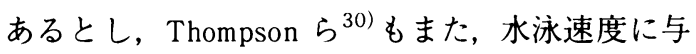
える効果は, 筋力トレーニングが水泳トレーニン グと同時に実施されれば効果があるが，ウエイ ト・トレーニングのみでは効果がないとしてい る.しかし, McKethan ら ${ }^{23)}$ がマシーンを用いて 行った複合トレーニング (isometrics-isotonics)で は, 筋力のみの增加で, 垂直跳びには向上がみら れなかった。田路ら ${ }^{31)}$ は垂直跳び能力に及ほす 複合トレーニングの研究において, テスト運動と 同じ垂直跳びを反復する単一負荷のトレーニング よりも，垂直跳びと筋力トレーニングを同時に行 う複合トレーニングの方がより効果的であると報 告している.

本研究の結果はこの田路ら ${ }^{31)}$ の成果を基本的 に支持するものであるが，運動条件が相違する. すなわち垂直跳びでは, 負荷条件が個人の体重で 
ある.しかしこの点については,「垂直跳び型運 動の最大パワーは体重 $(1 \mathrm{G})$ 条件下で出現する」 との知見が月面跳躍の研究から得られている 4 . 12).すなわち「最大パワーの発現」を共通項と して〈体重 $\left.\fallingdotseq 30 \% \mathrm{P}_{0}\right\rangle$ の対応が考えられるわけで, このことは両研究のむしろ類似性を示唆するもの である.また, 本研究の単関節運動におけるトレー ニング効果が垂直跳びの実験成績 ${ }^{31)}$ と基本的に 一致したことは，局部的な神経・筋のコーディ ネーションや筋の動特性における変化が, 垂直跳 びパワーの増加に深く関わっていたことを示唆す る。

筋自体の力学的特性については，その実態を 力ー速度関係を通して組織的に知ることができ $3^{15,18)}$. 力-速度曲線の湾曲度 $\mathrm{a} / \mathrm{P}_{0}$ (生理学的に は最大筋力に対する内部抵抗の大きさ15) $)$ に関し ては，筋線維組成による差異 ${ }^{5.8)}$ やトレーニング の影響 ${ }^{11,19)}$ が報告されており，本研究の各群に おける力-速度曲線にも多かれ少なかれトレーニ ングによる特徵的な変化(双曲線の平行移動)が見 られた (Fig. 2). その結果としての最大パワー $\left(\mathrm{PV}_{\max }\right)$ は,

$$
P V_{\max }=\left(\frac{P_{m}}{P_{0}}\right)^{2} P_{0} \cdot V_{0}
$$

または,

$$
P V_{\max }=\left[\frac{a}{P_{0}}\left(\sqrt{1+\frac{P_{0}}{a}}-1\right)\right]^{2} P_{0} \cdot V_{0}
$$

の関係にある．本研究の $\mathrm{a} / \mathrm{P}_{0}$ 比に有意な変化が なく，また式(4)における $\mathrm{P}_{\mathrm{m}} / \mathrm{P}_{0}$ 比も， G 30 群で $0.344 \rightarrow 0.339$, G $30+0$ 群で $0.341 \rightarrow 0.334$, G 30 +100 群で $0.333 \rightarrow 0.327$ (有意ではないが)隇少 傾向を示したことから, $\mathrm{PV}_{\text {max }}$ の増加が $\mathrm{P}_{0}$ また は $\mathrm{V}_{0}$ の増加に起因するものであったことが示唆 される。

最大パワーを高める生理学的要因に関して森谷 $ら^{25)}$ は, $1 / 3 \mathrm{P}_{0}$ 負荷のトレーニングによる最大 パワーの有意な増加を認めるとともに, 筋電図の パワースペクトラム分析を通して筋放電の量的増 加と同期化が起こることを指摘している. Behm
ら は，動的運動におけるトルクやスピードを高 めるトレーニングにおいて，動きを伴った運動刺 激は必ずしも必要でなく，(等尺性収縮でも) 素早 く動かそうとする心理的な速度 (induced move. ment velocity) が重要なトレーニング刺激になる ことを実験的に示した。また，母指内転筋の力速度関係に対するトレーニング効果を検討した Duchateau と Hainant ${ }^{11)}$ の研究では，等尺性筋力 トレーニングによる最大パワーの増加と, 等張力 性トレーニングによる (単収縮) 張力発生速度の改 善が報告された。これらの知見を考虑すると，本 研究の $\mathrm{G} 30+100$ 群における最大パワーの著名 な増加には, 筋肥大の要因を含む筋力増加 ${ }^{13)}$, 神経・筋のコーディネーションにおける改善 ${ }^{26)}$ など,さまざまな要因の関係したことが推察され る.

\section{V. 要 約}

时屈筋群の力-速度関係とパワーに及はす複合 トレーニングの効果を知るため, 一般男子大学生 18名を次の 3 群に分け, 週 3 日, 11週間のトレー ニングを行った.すなわちトレーニング群は，1） 最大筋力の $30 \%$ 負荷 $\left(30 \% \mathrm{P}_{0}\right)$ で最大パワーを発 揮する単一トレーニング群 (G 30群)，2）最大パ ワーの発揮に加え, 無負荷 $\left(0 \% \mathrm{P}_{0}\right)$ で最大速度 を発揮する複合トレーニング群 (G 30+0 群)， 3) 最大パワーの発揮に加え, 最大筋力 $\left(100 \% \mathrm{P}_{0}\right)$ を 発揮する複合トレーニング群 (G 30+100 群)の 3 群とし, 次の結果を得た。

1. 最大パワーの増加は $\mathrm{G} 30+100$ 群で最も 著しく, 次いで G $30+0$ 群, G 30 群の順となり， それらすべてが統計的に有意な増加であった．ま た, G $30+100$ 群と $\mathrm{G} 30+0$ 群の増加量間に有意 差が認められた。

2. 最大筋力の増加は $\mathrm{G} 30+100$ 群で最も著 しく, 次いで $\mathrm{G} 30$ 群, $\mathrm{G} 30+0$ 群の順で, 上位2 群の増加に有意性が見られた。また $\mathrm{G} 30+100$ 群と G 30 群の増加量間に有意差が認められた。

3. 最大速度はすべての群で有意に増加した が, 各群の増加量間には有意差が認められなかっ た。 
以上の結果から，パワー・トレーニングにおい て, 筋力強化を加えた複合トレーニングは, 単一 負荷のトレーニングと同様に優れた効果を発揮す るとともに，スピードを重視した複合トレーニン グよりも効果的であることが示唆された。

本研究のデーター処理に当り, 大阪体育大学渕本隆 文氏の貴重なアドバイスを得た，記して感謝の意を表 します.

(受付 平成 7 年 1 月 19 日)

\section{文献}

1) Behm, D.G., \& Sale, D. G. Intended rather than actual movement velocity determines velocityspecific training response. J. Appl. Physiol., (1993), 74, 359-368.

2) Belka, D. E. Comparison of dynamic, static, and combination training on dominant wrist flexor muscle. Res. Quart., (1968), 39, 244-250.

3) Caiozzo, V. J., Perrine, J. J., \& Edgerton, V. R. Training-induced alterations of the in vivo forcevelocity relationship of human muscle. J. Appl. Phy siol., (1981), 51, 750-754.

4) Cavagna, G. A., Zamboni, A., Faraggia, T., \& Margaria, R. Jumping on the moon: Power output at different gravity values. Aerospace Medicine, (1972), 43, 408-414.

5) Close, R. I. Dynamic properties of mammalian skeletal muscles. Physiol. Rev., (1972), 52, 129-197.

6) Clutch, D., Wilton, M., McGown, C., \& Bryce, G. R. The effect of depth jumps and weight training on leg strength and vertical jump. Res. Quart. Exerc. Sport, (1983), 54, 5-10.

7) Coyle, E. F., Feiring, D. C., Cote III , R. W., \& Wilmore, J. H. Specificity of power improvements through slow and fast isokinetic training. J. Appl. Physiol., (1981), 51, 1437-1442.

8) De Koning, F. L., Vos, J. A., Binkhorst, R. A., \& Vissers, A. C. A. Influence of training on the forcevelocity relationship of the arm flexors of active sportsmen. Int. J. Sports Med., (1984), 5, 43-46.

9) Dintiman, G. B. Effects of various training programs on running speed. Res. Quart., (1964), 35, 456-463.

10) Doherty, T. J. \& Campagna, P. D. The effects of periodized velocity-specific resistance training on maximal and sustained force production in women.
J. Sports Sci., (1993), 11, 77-82.

11) Duchateau, J. \& Hainaut, K. Isometric or dynamic training: differential effects on mechanical properties of a human muscle.J. Appl. Physiol.: Respir. at. Environ.Exerc. Physiol., (1984), 56, 296-301.

12）㴊本隆文, 駒井博和, 金子公有. 月面重力を含む種々 負荷条件下での跳躍運動とパワー出力, 大阪体育 大学紀要, (1994), 25, 79-81.

13）福永哲夫, 杉山允宏. 絶体筋力におよほす静的お よび動的筋力トレーニングの影響, 体育学研究, (1978), 22, 343-349.

14) Hakkinen, K., Komi, P. V., \& Tesch, P. A. Effect of combined concentric and eccentric strength training and detraining on force-time, muscle fiber and metabolic characteristics of leg extensor muscles. Scand. J. Sports Sci., (1981), 3, 50-58.

15) Hill, A. V. The heat of shortening and the dynamic constants of muscle. Proc. Roy. Soc. B, (1938), 126. 136-195.

16) Jackson, A., Jackson, T., Hnatek, J., \& West, J. Strength development: using functional isometrics in an isotonic strength training program. Res. Quart. Exerc. Sport, (1985), 56, 234-237.

17) Kanehisa, H. \& Miyasita, M. Effect of isometric and isokinetic muscle training on static strength and dynamic power. Eur. J. Appl. Physiol., (1983), 50, 365-371.

18）金子公有. 瞬発的パワーからみた人体筋のダイナ ミクス, 初版, 力-速度関係からみた筋パワーの分 析, 杏林書院, 東京, (1974), 73-92.

19) Kaneko, M., Fuchimoto, H., Toji, H., \& Suei, K. Training effect of different loads on the forcevelocity relationship and mechanical power output in human muscle. Scand. J. Sports Sci., (1983), 5 , 50-55.

20）金子公有, 末井健作, 田路秀樹, 㴊本隆文. 瞬発 力におよほす筋トレーングの効果, 体育科学, (1983)，11，24-30.

21）金子公有, 田路秀樹, 末井健作. 中学生の跳運動 (垂 直跳・立幅跳)におけるパワーとパフォーマンスに 及はすトレーニング効果, 体育科学, $(1984), 12$, 33-38.

22）金子公有, 末井健作, 田路秀樹. 中学生の疾走能 力に及ほす 3 種トレーニングの効果, 体育科学, (1985) , 13, 78-84.

23) McKethan, J. F., \& Mayhew, J. L. Effects of isometrics, isotonics, and combined isometricsisotonics on quadriceps strength and vertical jump. J. Sports Med., (1974), 14, 224-229. 
24) Moffroid, M., \& Whipple, R. H. Specificity of speed of exercișe. Phys. Therapy, (1970), 50, 1692-1700.

25）森谷敏夫, 室 増男, 石田浩司, 田口貞善. 筋パワー トレーニング効果の電気生学的研究, スポーツ医・ 科学, (1987), 1, 23-32.

26) Moritani, T. Neuromuscular adaptations during the acquisition of muscle strength, power and motor tasks. J. Biomech., (1993), 26, (suppl. 1), 95-107.

27) Sale, D. \& MacDougall, D. Specificity in strength training: A review for the coach and athlete. Can. J. Appl. Sport Sci., (1981), 6, 87-92.

28) Schultz, G. W. Effects of direct practice, repetitive sprinting, and weight training on selected motor performance tests. Res. Quart., (1967), 38, 108-118.

29) Smith, L. E. Influence of strength training on pre-tensed and free-arm speed. Res. Quart, (1964). 35, 554-561.

30) Thompson, H. L. \& Stull, G. A. Effects of various training programs on speed of swimming. Res. Quart., (1959), 30, 479-485.

31）田路秀樹, 末井健作, 金子公有. 跳躍のパフォー マンスにおよはす複合トレーニング刺激の効果, 体育の科学, (1989), 39, 305-308.

32) Whitley, J. D. \& Smith, L. E. Influence of three different training programs on strength and speed of a limb movement. Res. Quart., (1966), 37, 132-142.

33) Wilkie, D. R. The relation between force and velocity in human muscle. J. Physiol., (1950), 110. 249-280. 